\title{
HUBUNGAN FAKTOR INDIVIDU, DURASI KERJA, DAN TINGKAT RISIKO ERGONOMI TERHADAP KEJADIAN MUSCULOSKELETAL DISORDERS PADA PENENUN SONGKET PANDAI SIKEK
}

\author{
Zahra Halfa' Badriyyah $^{1^{*}}$, Yuliani Setyaningsih ${ }^{2}$, Ekawati ${ }^{2}$ \\ ${ }^{1}$ Peminatan Keselamatan dan Kesehatan Kerja Fakultas Kesehatan Masyarakat Universitas \\ Diponegoro JI. Prof. H. Soedarto, S.H.,Tembalang, Semarang, Indonesia \\ ${ }^{2}$ Bagian Keselamatan dan Kesehatan Kerja, Fakultas Kesehatan Masyarakat, Universitas Diponegoro \\ Jl. Prof. H. Soedarto, S.H.,Tembalang, Semarang, Indonesia \\ ${ }^{*}$ Corresponding author: zahrahalfabadriyvah@gmail.com
}

\begin{abstract}
Musculoskeletal Disorders (MSDs) are disorders due to injury to muscles, tendons, ligaments, nerves, cartilage, bones, or blood vessels ranging from complaints of mild to very severe pain. This study aims to analyze individual factors and occupational factors related to the incidence of Musculoskeletal Disorders in songket weavers in Nagari Pandai Sikek, West Sumatra. This research is an analytic observational research with a cross sectional study design. The research sample was songket weavers totaling 70 people. Chi-square analysis showed that age ( $p$-value $=0.005)$, years of service ( $p$-value $=0.008)$, history of disease $(p$-value $=0.001)$, work duration $(p$-value $=0.000)$, and level of ergonomics risk ( $p$-value $=0.002$ ) had significant correlation with Musculoskeletal Disorders. This study also showed that the complaints most felt by weavers were in the waist (97.1\%), back (94.3\%), right shoulder (78.6\%), bottom (77.1\%), and left shoulder (77.1\%).
\end{abstract}

Keywords : musculoskeletal disorders, ergonomic risk level, songket weavers

\section{PENDAHULUAN}

Penerapan kesehatan dan keselamatan kerja (K3) merupakan hal yang sangat penting dalam suatu pekerjaan baik sektor formal maupun sektor informal. Namun di banyak negara lebih dari separuh pekerja sektor informal bekerja tanpa adanya perlindungan sosial maupun perlindungan kesehatan serta tidak adanya penegakan peraturan standar K3. ${ }^{1}$

Di Indonesia hal ini dapat dilihat dari angka kecelakaan kerja. Pada tahun 2017, terjadi 123.041 kasus kecelakaan kerja dan mencapai 173.105 kasus di sepanjang tahun 2018. Laporan pada tahun 2019 juga menyatakan bahwa BPJS Ketenagakerjaan melayani hingga 130 ribu kasus kecelakaan kerja pertahun baik berupa kasus ringan maupun kasus yang berdampak fatal. ${ }^{2}$

Pada tahun 2013, ILO menyatakan bahwa 1 orang pekerja di dunia meninggal setiap 15 detik akibat kecelakan kerja sementara 160 pekerja lainnnya menderita penyakit akibat kerja dan sebanyak 2 juta kasus kematian terjadi akibat kecelakaan kerja dan penyakit akibat kerja setiap tahunnya. ${ }^{3}$

Musculoskeletal Disorders menjadi penyakit akibat kerja yang penting dalam kejadian kesakitan dan kecacatan pada pekerja. Dari kasus penyakit akibat kerja yang terjadi, 37\% merupakan kasus nyeri punggung, $16 \%$ gangguan pendengaran, $13 \%$ penyakit paru-paru obstruktif, $11 \%$ asma, $8 \%$ cedera, $9 \%$ kanker paru-paru, $2 \%$ leukemia dan $8 \%$ depresi. ${ }^{1}$ Dan di Indonesia pada tahun 2013, angka prevalensi keluhan muskuloskeletal diketahui mencapai $24,7 \%{ }^{4}$

Musculoskeletal Disorders merupakan gangguan pada otot, saraf, tendon, sendi, tulang, tulang rawan, dan struktur lainnya atau diperburuk oleh pengerahan tenaga yang tibatiba atau paparan yang terlalu lama dari berbagai faktor dalam pekerjaan kecuali kondisi seperti patah tulang, memar, lecet, dan luka akibat kontak fisik yang tiba-tiba dengan objek eksternal dan dapat terjadi di berbagai area tubuh seperti leher, bahu, pergelangan tangan, pinggul, lutut, dan tumit. 5,6

Proses kerja yang dilakukan secara berulang-ulang, membutuhkan waktu yang lama, dan dengan postur kerja tidak ergonomis akan mengakibatkan timbulnya gangguan pada tubuh seperti kelelahan kronis dan Musculoskeletal Disorders. ${ }^{7}$

Salah satu pekerjaan yang berisiko terjadinya Musculoskeletal Disorders adalah penenun songket karena posisi kerja statis dan dilakukan dalam waktu yang lama. Selain itu, postur kerja tidak ergonomis juga terjadi selama bekerja seperti postur membungkuk pada saat pembentukan pola (bending), posisi menjangkau (reaching), dan memutar badan saat memasukkan benang (twisting). ${ }^{7}$ 


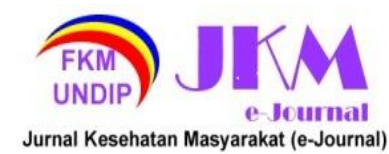

Oleh karena itu, penelitian ini dilakukan untuk mengetahui faktor-faktor yang mempengaruhi terjadinya Musculoskeletal Disorders pada penenun Songket Pandai Sikek.

\section{METODE PENELITIAN}

Penelitian ini dilaksanakan di Jorong Tanjuang, Nagari Pandai Sikek, Sumatera Barat pada bulan Mei - Juni 2021. Penelitian ini merupakan penelitian observasional analitik dengan desain studi cross sectional. Populasi dalam penelitian ini adalah seluruh penenun di Jorong Tanjuang Pandai Sikek. Pengambilan sampel menggunakan teknik incidental sampling dengan jumlah sampel sebanyak 70 orang.

Variabel bebas yang digunakan meliputi usia, masa kerja, riwayat penyakit, durasi kerja, dan tingkat risiko ergonomi terhadap variabel terikat yaitu terjadinya Musculoskeletal Disorders.

Data penelitian didapatkan melalui kuesioner dan observasi. Observasi dilakukan untuk mengamati postur tubuh pekerja sehingga bisa diketahui tingkat risiko ergonomi dari pekerjaan yang dilakukan menggunakan lembar REBA. Selain itu, juga dilakukan pengisian lembar Peta Keluhan Subjektif MSDs untuk mengetahui tingkat keluhan Musculoskeletal Disorders yang dirasakan oleh para penenun.

\section{HASIL DAN PEMBAHASAN \\ Gambaran Lokasi Penelitian}

Pandai Sikek merupakan sebuah nagar (desa) yang berada di Kabupaten Tanah Datar, Sumatera Barat yang memiliki topografi wilayah yang bergelombang dengan luas sekitar 2.150 $\mathrm{Ha}$ dan terdiri dari 4 jorong, yaitu Tanjuang, Baruah, Pagu-pagu, dan Koto Tinggi.

Penduduk di Nagari Pandai Sikek lebih kurang berjumlah 5.597 jiwa yang terdiri dari 2.771 laki-laki $(49,5 \%)$ dan 2.826 perempuan $(50,5 \%)$. Mata pencaharian penduduk di Nagari Pandai Sikek cukup beragam, tapi didominasi oleh pekerjaan sebagai petani dan penenun songket khas Pandai Sikek.

Tenun songket Pandai Sikek merupakan seni kerajinan yang sudah ada sejak beratusratus tahun yang lalu dan merupakan salah satu warisan budaya Indonesia yang sudah dikenal bahkan sampai ke mancanegara. Keterampilan bertenun biasanya dipelajari masyarakat sejak masih anak-anak dengan sistem pewarisan dari ibu ke anak dan hanya diperkenankan untuk penduduk asli Pandai Sikek. Hasil tenun yang disebut dengan kain songket ini akan dibuat menjadi souvenir serta produk-produk kreasi yang biasanya dipakai untuk upacara adat dan acara pernikahan.

Tabel 1. Hasil Uji Univariat

\begin{tabular}{llll}
\hline \multirow{2}{*}{ Variabel } & \multirow{2}{*}{ Kategori } & \multicolumn{2}{l}{ Frekuensi } \\
\cline { 3 - 4 } & & $\mathrm{N}$ & $\%$ \\
\hline Usia & Muda & 27 & 38,6 \\
& Tua & 43 & 61,4 \\
\hline Masa Kerja & Baru & 33 & 47,1 \\
& Lama & 37 & 52,9 \\
\hline Riwayat & Tidak Ada & 28 & 40 \\
Penyakit & Ada & 42 & 60 \\
\hline Durasi & Normal & 26 & 37,1 \\
Kerja & Lembur & 44 & 62,9 \\
\hline Tingkat & Sedang & 26 & 37,1 \\
risiko & Tinggi & 42 & 60,0 \\
ergonomi & Sangat Tinggi & 2 & 2,9 \\
\hline Keluhan & Ringan & 19 & 27,1 \\
Muskulo- & Sedang & 43 & 61,4 \\
skeletal & Berat & 8 & 11,4 \\
\hline
\end{tabular}

Usia penenun songket didominasi oleh usia tua atau lebih dari 35 tahun $(61,4 \%)$ dan berkisar antara 18 - 83 tahun dengan rata-rata usia sekitar 43 tahun. Masa kerja penenun antara 5 - 70 tahun dengan rata-rata telah bekerja selama 22 tahun. Waktu kerja penenun adalah sekitar 4 - 12 jam sehari dengan $62,9 \%$ penenun bekerja lebih dari 8 jam sehari. Hal ini karena sebagian besar penenun tersebut merupakan ibu-ibu yang tidak bekerja di ladang sehingga lebih banyak menghabiskan waktu di rumah dan menjadikan tenun sebagai mata pencaharian utama.

Selain itu diketahui bahwa 42 orang (60\%) penenun memiliki riwayat penyakit yang berkaitan dengan Musculoskeletal Disorders yaitu sebanyak 27 orang $(64,2 \%)$ mengalami tekanan darah rendah (hipotensi), 13 orang $(31 \%)$ mengalami tekanan darah tinggi (hipertensi), dan 2 orang (4,8\%) memiliki riwayat penyakit jantung.

Penelitian ini menggunakan form REBA untuk menentukan tingkat risiko ergonomi pada postur kerja penenun.dan didapatkan hasil yang menunjukkan bahwa tidak ada penenun yang memiliki risiko ergonomi rendah dan hanya terdapat penenun yang termasuk kategori risiko sedang, tinggi, maupun sangat tinggi.

Dan berdasarkan Peta Tubuh Keluhan Subjektif MSDs, diketahui bahwa lebih banyak penenun yang mengalami keluhan tingkat sedang $(61,4 \%)$ dengan bagian tubuh yang paling sering merasakan sakit adalah pada pinggang $(97,1 \%)$, punggung $(94,3 \%)$, bahu kanan $(78,6 \%)$, pantat $(77,1 \%)$, bahu kiri 


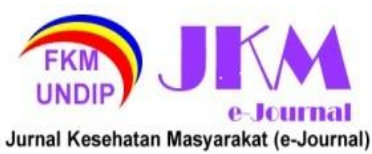

JURNAL KESEHATAN MASYARAKAT (e-Journal)

Volume 9, Nomor 6, November 2021

ISSN: 2715-5617 / e-ISSN: 2356-3346

http://ejournal3.undip.ac.id/index.php/jkm
$(77,1 \%)$, betis kanan $(75,7 \%)$, betis kiri $(74,3 \%)$, lengan atas kiri $(74,3 \%)$, dan lengan atas kanan $(72,6 \%)$. Sedangkan bagian tubuh yang paling sedikit mengalami keluhan sakit adalah siku kanan $(31,4 \%)$ dan siku kiri $(20 \%)$.

Tabel 2. Hasil Uji Bivariat

\begin{tabular}{|c|c|c|c|c|c|c|c|c|c|c|}
\hline \multirow{3}{*}{ Variabel } & \multirow{3}{*}{ Kategori } & \multicolumn{6}{|c|}{ Keluhan Muskuloskeletal } & \multirow{2}{*}{\multicolumn{2}{|c|}{ Total }} & \multirow{3}{*}{$p$-value } \\
\hline & & \multicolumn{2}{|c|}{ Ringan } & \multicolumn{2}{|c|}{ Sedang } & \multicolumn{2}{|c|}{ Berat } & & & \\
\hline & & $f$ & $\%$ & $\mathrm{~F}$ & $\%$ & $\mathrm{~F}$ & $\%$ & $f$ & $\%$ & \\
\hline \multirow[t]{2}{*}{ Usia } & Muda & 13 & 48,1 & 13 & 48,1 & 1 & 3,8 & 27 & \multirow[b]{2}{*}{100} & \multirow[b]{2}{*}{0,005} \\
\hline & Tua & 6 & 14 & 30 & 69,8 & 7 & 16,2 & 43 & & \\
\hline \multirow{2}{*}{$\begin{array}{l}\text { Masa } \\
\text { Kerja }\end{array}$} & Baru & 14 & 42,4 & 18 & 54,6 & 1 & 3 & 33 & \multirow[b]{2}{*}{100} & \multirow{2}{*}{0,008} \\
\hline & Lama & 5 & 13,5 & 25 & 67,6 & 7 & 18,9 & 37 & & \\
\hline \multirow{2}{*}{$\begin{array}{l}\text { Riwayat } \\
\text { Penyakit }\end{array}$} & Tidak Ada & 14 & 50 & 13 & 46,4 & 1 & 3,6 & 28 & \multirow{2}{*}{100} & \multirow{2}{*}{0,001} \\
\hline & Ada & 5 & 11,9 & 30 & 71,4 & 7 & 16,7 & 42 & & \\
\hline \multirow{2}{*}{$\begin{array}{l}\text { Durasi } \\
\text { Kerja }\end{array}$} & Normal & 14 & 53,9 & 11 & 42,3 & 1 & 3,8 & 26 & \multirow[b]{2}{*}{100} & \multirow[b]{2}{*}{0,000} \\
\hline & Lembur & 5 & 11,4 & 32 & 72,7 & 7 & 15,9 & 44 & & \\
\hline \multirow{3}{*}{$\begin{array}{l}\text { Tingkat } \\
\text { Risiko } \\
\text { Ergonomi }\end{array}$} & Sedang & 14 & 53,9 & 11 & 42,3 & 1 & 3,8 & 26 & \multirow{3}{*}{100} & \multirow{3}{*}{0,002} \\
\hline & Tinggi & 4 & 9,5 & 31 & 73,8 & 7 & 16,7 & 42 & & \\
\hline & Sangat Tinggi & 1 & 50 & 1 & 50 & 0 & 0 & 2 & & \\
\hline
\end{tabular}

\section{Hubungan Antara Usia dengan Musculoskeletal Disorders}

Usia mempunyai hubungan yang sangat erat dengan kekuatan otot, bahkan para ahli menyatakan bahwa usia merupakan penyebab utama terjadinya keluhan pada otot, karena semakin tua atau bertambahnya usia maka kekuatan otot semakin berkurang dan terjadi penurunan kemampuan kerja karena perubahan pada fungsi tubuh. ${ }^{8,9}$

Berdasarkan hasil uji statistik diperoleh nilai signifikansi usia sebesar 0.005 ( $p$-value < $0,05)$, sehingga dapat disimpulkan bahwa terdapat hubungan yang bermakna antara usia dengan Musculoskeletal Disorders pada penenun songket Pandai Sikek.

Hasil penelitian ini sejalan dengan penelitian yang dilakukan oleh Pandu Revi Ami Sandi dkk yang menyatakan bahwa usia berpengaruh terhadap kejadian Musculoskeletal Disorders. Dalam penelitian ini, usia merupakan faktor yang lebih dominan menyebabkan kejadian Musculoskeletal Disorders pada pekerja pabrik tenun Masari Pemalang. ${ }^{10}$

Dan berdasarkan penelitian yang dilakukan oleh Sherli Shobur dkk pada pekerja tenun ikat di Kelurahan Tuan Kentang Kota Palembang ditemukan bahwa pekerja yang berumur tua atau lebih dari umur 35 tahun mempunyai peluang 8.000 kali lebih berisiko untuk mengalami Musculoskeletal Disorders dibandingkan pekerja yang berumur muda. ${ }^{11}$

\section{Hubungan Antara Masa Kerja dengan} Musculoskeletal Disorders

Lamanya seseorang bekerja terutama untuk tugas yang sama akan berkaitan dengan ketahanan fisik seseorang. Apabila aktivitas tersebut dilakukan secara terus menerus dan dalam jangka waktu yang lama akan mengakibatkan gangguan pada tubuh. Semakin lama masa kerja seseorang maka akan semakin besar resiko terkena penyakit akibat kerja salah satunya Musculoskeletal Disorders. ${ }^{12}$

Keluhan Musculoskeletal Disorders akan semakin bertambah ketika masa kerja seseorang juga bertambah. Selain itu juga terjadi kejenuhan baik secara fisik maupun secara psikis. Masa kerja merupakan faktor risiko yang sangat mempengaruhi terjadinya Musculoskeletal Disorders pada penenun, terutama untuk jenis pekerjaan yang menggunakan kekuatan kerja yang tinggi. Bertambahnya masa kerja akan memberi pengaruh positif dan negatif, yaitu akan memberikan pengaruh positif pada kinerja personal karena dengan bertambahnya masa kerja maka berbanding lurus dengan bertambahnya pengalaman dalam melaksanakan pekerjaan. Sedangkan pengaruh negatif yaitu akan muncul kebiasaankebiasaan yang tidak baik pada pekerja. ${ }^{13}$

Dari hasil uji statistik diperoleh nilai signifikansi sebesar 0.008 ( $p$-value $<0,05)$, 


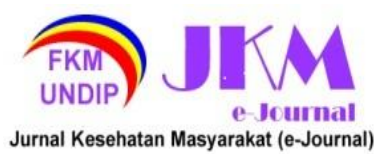

sehingga dapat disimpulkan bahwa terdapat hubungan yang bermakna antara masa kerja dengan kejadian Musculoskeletal Disorders pada penenun songket Pandai Sikek.

Penenun Pandai Sikek umumnya memiliki masa kerja lebih dari 10 tahun karena kebanyakan penenun telah mulai belajar menenun sejak usia sekolah dasar. Sebagian besar penenun yang masih usia sekolah tetap bertenun setelah pulang sekolah atau di saat waktu luang dan bahkan setelah lulus sekolah hingga menikah pun mereka tetap menjadikan pekerjaan ini sebagai mata pencaharian utama sehingga dengan masa kerja yang sangat lama para penenun cukup berisiko untuk mengalami Musculoskeletal Disorders.

Hasil penelitian ini sejalan dengan penelitian yang dilakukan oleh Daryatno Mufsidik dkk yang menyatakan bahwa terdapat hubungan yang signifikan antara masa kerja dengan terjadinya keluhan Musculoskeletal Disorders (MSDs) pada penenun di Desa Masalili Kecamatan Kontunaga Kabupaten Muna. ${ }^{12}$

\section{Hubungan Antara Riwayat Penyakit dengan Musculoskeletal Disorders}

Beberapa jenis penyakit yang dapat mempengaruhi terjadinya Musculoskeletal Disorders antara lain adalah osteoporosis karena berkurangnya kepadatan massa tulang, penyakit jantung karena ketidakseimbangan kebutuhan oksigen pada tubuh, penyakit ginjal karena gangguan metabolisme, tekanan darah rendah karena terbentuknya asam laktat, dan tekanan darah tinggi karena terhambatnya aliran darah. ${ }^{14}$

Dari hasil uji statistik diperoleh nilai signifikansi sebesar 0,001 ( $p$-value $<0,05$ ), sehingga dapat disimpulkan bahwa terdapat hubungan yang bermakna antara riwayat penyakit dengan Musculoskeletal Disorders pada penenun songket Pandai Sikek.

Hasil penelitian ini sejalan dengan penelitian yang dilakukan oleh Muhammad Ardiansyah dkk yang menyatakan bahwa ada hubungan yang bermakna antara riwayat penyakit dengan kejadian Musculoskeletal Disorders dan menjadi variabel yang paling berpengaruh terhadap keluhan MSDs pada Penenun Lipa' Sa'be Mandar di Desa Karama Kabupaten Polewali Mandar. ${ }^{14}$

\section{Hubungan Antara Durasi Kerja dengan Musculoskeletal Disorders}

Jumlah waktu kerja dalam sehari pada umumnya adalah selama $6-10$ jam sehingga sisanya dapat dipergunakan untuk istirahat, tidur, bersosialisasi, dan lain-lain. Durasi kerja yang terlalu panjang akan mengakibatkan terjadinya kelelahan, gangguan kesehatan, penyakit, kecelakaan, serta ketidakpuasan. ${ }^{9}$

Semakin lama durasi kerja seseorang maka akan semakin tinggi pula risiko yang akan diterima dan semakin lama pula waktu yang diperlukan untuk pemulihan tenaganya, sehingga harus ada kesesuaian antara waktu bekerja dengan waktu istirahat untuk mengurangi risiko terjadinya Musculoskeletal Disorders. ${ }^{15}$

Dari hasil uji statistik diperoleh nilai signifikansi sebesar 0,000 ( $p$-value $<0,05$ ), sehingga dapat disimpulkan bahwa terdapat hubungan yang bermakna antara durasi kerja dengan Musculoskeletal Disorders pada penenun songket Pandai Sikek.

Sebanyak $72,7 \%$ penenun songket Pandai Sikek memiliki durasi kerja $>8$ jam sehari. Biasanya penenun mulai bekerja pada jam 8 pagi hingga jam 6 sore dengan waktu istirahat yaitu pada waktu Shalat Zuhur dan Shalat Ashar. Setelah itu, penenun melanjutkan pekerjaan pada malam hari setelah waktu Shalat Isya hingga jam 9 malam atau sekitar 2 jam. Hal ini biasanya terjadi jika penenun mendapat pesanan songket secara mendadak sehingga harus diselesaikan secepat mungkin untuk memenuhi permintaan pelanggan.

Hasil penelitian ini sejalan dengan penelitian yang dilakukan oleh Sherli Shobur dkk yang menyatakan bahwa terdapat hubungan antara lama kerja dengan terjadinya Musculoskeletal Disorders pada pekerja Tenun Ikat di Kelurahan Tuan Kentang Kota Palembang. Pekerja dengan lama kerja $\geq 8$ jam berisiko 6,708 kali lebih besar untuk mengalami Musculoskeletal Disorders dibandingkan dengan yang bekerja $<8$ jam dalam sehari. ${ }^{11}$

\section{Hubungan Antara Tingkat Risiko Ergonomi dengan Musculoskeletal Disorders}

Tingkat risiko ergonomi dihitung berdasarkan posisi atau postur kerja seseorang dalam melaksanakan pekerjaannya. Posisi statis dalam waktu yang lama menyebabkan terjadinya kontraksi pada otot yang statis sehingga terjadi peningkatan tekanan pada otot yang mengakibatkan terjadinya kompresi pembuluh darah dalam otot. Kompresi pembuluh darah dalam otot menyebabkan terjadinya penurunan pada kadar oksigen sehingga terjadi kelelahan dan stress mekanik lokal pada otot, ligamen, dan persendian. ${ }^{16}$

Sikap kerja tidak alamiah pada umumnya terjadi karena ketidaksesuaian pekerjaan dengan kemampuan pekerja dan 


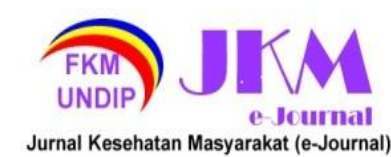

menyebabkan bagian tubuh bergerak menjauhi posisi alamiahnya. Semakin jauh posisi bagian tubuh dari pusat gravitasi, semakin tinggi risiko terjadinya Musculoskeletal Disorders.

Postur janggal juga akan membuat tubuh berusaha lebih keras untuk mempertahankan kontraksi otot statis. Saat otot menjadi fatigue dan tetap terjadi kontraksi yang berkepanjangan maka menyebabkan iskemia pada otot. ${ }^{17}$ Seperti posisi duduk akan memberi tekanan pada vertebra lumbal sehingga menimbulkan nyeri pada punggung bawah. ${ }^{18}$

Dari hasil uji statistik diperoleh nilai signifikansi sebesar 0,002 ( $p$-value $<0,05$ ), sehingga dapat disimpulkan bahwa terdapat hubungan yang bermakna antara tingkat risiko ergonomi dengan terjadinya Musculoskeletal Disorders pada penenun songket Pandai Sikek.

Risiko ergonomi dari pekerjaan menenun ini disebabkan oleh postur janggal seperti menunduk, membungkuk, menjangkau, dan mendorong yang dilakukan berulang kali dalam waktu yang lama. Proses pekerjaan yang harus dilakukan dalam posisi duduk juga mengakibatkan penekanan berlebihan pada tubuh selama berjam-jam. Selain itu, alat tenun yang tidak ergonomis dan tidak sesuai dengan antropometri tubuh penenun mengakibatkan beberapa penenun harus mempertahankan posisi tubuh dengan cara berjinjit di lantai.

Keluhan di bagian pinggang dan punggung dapat terjadi karena posisi tubuh yang cenderung condong ke depan selama bertenun. Sedangkan posisi kerja yang mengharuskan penenun untuk selalu duduk mengakibatkan sakit pada bagian pantat. Selain itu, proses pengerjaan songket yang didominasi oleh pekerjaan tangan seperti mendorong dan menjangkau secara berulang mengakibatkan terjadinya keluhan pada bahu.

Hasil penelitian ini sejalan dengan penelitian yang dilakukan oleh Tiara Putri Yosineba dkk yang menyatakan bahwa terdapat hubungan antara risiko ergonomi dengan keluhan muskuloskeletal pada pengrajin tenun di Kota Palembang. Hal ini karena pekerja menggunakan kursi yang tidak ergonomis yaitu tidak memiliki sandaran punggung dan tidak didesain sesuai dengan antropometri tubuh pekerja. ${ }^{19}$

\section{KESIMPULAN}

Dari penelitian ini dapat disimpulkan bahwa terdapat hubungan antara usia, masa kerja, riwayat penyakit, durasi kerja, dan tingkat risiko ergonomi dengan kejadian Musculoskeletal Disorders pada penenun songket di Nagari Pandai Sikek. Seluruh responden mengalami Musculoskeletal Disorders dengan jumlah keluhan tingkat ringan $27,1 \%$, tingkat sedang $61,4 \%$, dan tingkat berat $11,4 \%$. Selain itu, bagian tubuh penenun yang paling sering mengalami keluhan sakit adalah bagian pinggang $(97,1 \%)$, punggung $(94,3 \%)$, bahu kanan $(78,6 \%)$, pantat $(77,1 \%)$, dan bahu kiri $(77,1 \%)$.

Untuk mengurangi risiko terjadinya Musculoskeletal Disorders, penenun disarankan untuk istirahat selama 5 - 10 menit setelah 2 jam bekerja, melakukan olahraga rutin minimal 2 kali seminggu untuk menjaga kebugaran tubuh, dan menggunakan tambahan pijakan apabila kaki tidak dapat menjangkau lantai sehingga kaki tertopang dengan baik.

\section{DAFTAR PUSTAKA}

1. World Health Organization. Protecting worker's health. 2017. Available from: https://www.who.int/news-room/factsheets/detail/protecting-workers'-health [accessed 1 June 2021].

2. BPJS Ketenagakerjaan. Angka Kecelakaan Kerja Cenderung Meningkat, BPJS Ketenagakerjaan Bayar Santunan Rp1,2 Triliun. 2019. Available from: https://www.bpjsketenagakerjaan.go.id/berit a/23322/Angka-Kecelakaan-Kerja-Cender [accessed 1 June 2021].

3. International Labour Organization. Keberlanjutan melalui Perusahaan yang Kompetitif dan Bertanggung Jawab (SCORE). Manajemen Sumber Daya Manusia untuk Kerjasama dan Usaha yang Sukses. Jakarta; 2013.

4. Balitbang Kemenkes RI. Riset Kesehatan Dasar: Riskesdas. Balitbang Kemenkes RI. Jakarta; 2013.

5. Cho K, Cho HY, Han GS. Risk Factors Associated With Musculoskeletal Symptoms In Korean Dental Practitioners. JPTS. 2016; 28(1):56-62.

6. The National Institute for Occupational Safety and Health. Musculoskeletal Health Program. 2017. Available from: http://www.cdc.gov/niosh/programs/msd/ [accessed 1 June 2021].

7. Mufti D, Suryani E, Sari N. Kajian Postur Kerja Pada Pengrajin Tenun Songket Pandai Sikek. Jurnal IImiah Teknik Industri. 2013; 12(1): 62-72.

8. Tarwaka. Ergonomi Industri Dasar-Dasar Pengetahuan Ergonomi dan Aplikasi di Tempat Kerja. Surakarta: Badan Penerbit Harapan Press; 2015. 


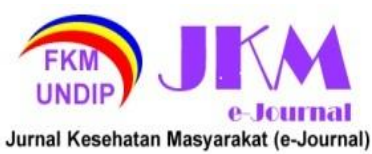

JURNAL KESEHATAN MASYARAKAT (e-Journal)

Volume 9, Nomor 6, November 2021

ISSN: 2715-5617 / e-ISSN: 2356-3346

http://ejournal3.undip.ac.id/index.php/jkm
9. Suma'mur. Higiene Perusahaan dan Keselamatan Kerja (HIPERKES). Jakarta: Sagung Seto; 2013.

10.Sandi PR, Ekawati E, Suroto S. Pengaruh Karakteristik Pekerja Terhadap Kejadian Musculoskeletal Disorder Pada Pekerja Pabrik Tenun Masari Pemalang. Jurnal Kesehatan Masyarakat. 2015;3(1):429-436.

11.Shobur S, Maksuk M, Sari FI. Faktor Risiko Musculoskeletal Disorders (MSDs) pada Pekerja Tenun Ikat di Kelurahan Tuan Kentang Kota Palembang. Jurnal Media Informasi Kesehatan. 2019;6(2):113-122.

12. Mufsidik D, Pratiwi AD, Junaid J. Faktor yang Berhubungan dengan Keluhan Musculoskeletal Disorders (MSDs) pada Penenun di Desa Masalili Kecamatan Kontunaga Kabupaten Muna Tahun 2019. Jurnal Ilmiah Mahasiswa Kesehatan Masyarakat. 2019;4(4).

13.Bukhori E. Hubungan Faktor Risiko Pekerjaan dengan Terjadinya Keluhan Musculoskeletal Disorders (MSDs) pada Tukang Angkut Beban Penambang Emas di Kecamatan Cilograng Lebak Banten [skripsi]. Jakarta: Universitas Islam Negeri Syarif Hidayatullah; 2010.

14.Adriansyah M, Mallapiang $F$, Ibrahim, $H$. Faktor yang Berhubungan dengan Keluhan Musculosceletal Disorders (MSDs) pada Penenun Lipa' Sa'be Mandar di Desa Karama Kecamatan Tinambung Kabupaten Polewali Mandar. HIGIENE: Jurnal Kesehatan Lingkungan. 2020;5(2),79-85.

15.Randang MJ. Hubungan Antara Umur, Masa Kerja dan Lama Kerja dengan Keluhan Musculoskeletal pada Nelayan di Desa Talikuran Kecamatan Remboken Kabupaten Minahasa. Jurnal Media Kesehatan. 2017;9(3):1-8.

16. Anghel M, Lungeanu D, Argesanu V, Niculescu CT. Musculoskeletal Disorders (MSDs) - Consequences of Prolonged Static Postures. J Exp Med Surg Res. 2007.

17. Valachi B, Valachi K. Mechanisms Leading to Musculoskeletal Disorders in Dentistry. Jurnal American Dental Association. 2003;134(10):1344-50.

18. Nurrahman R. Hubungan Masa Kerja dan Sikap Kerja terhadap Kejadian Low Back Pain pada Penenun di Kampoeng BNI Kab.Wajo [skripsi]. Makassar: Universitas Hasanuddin Makassar; 2016.

19. Yosineba TP, Bahar E, Adnindya MR. Risiko Ergonomi dan Keluhan Musculoskeletal Disorders (MSDs) pada Pengrajin Tenun di Palembang. Jurnal Kedokteran dan Kesehatan: Publikasi IImiah
Fakultas Kedokteran Universitas Sriwijaya. 2020;7(1):60-6. 